\title{
Problems of Countering Twilight Processes in Modern Economic Conditions
}

\author{
Irina Logvinova ${ }^{1}$, Anna Zhigunova ${ }^{1, *}$, Maxim Selischev ${ }^{1}$, and Anastasia Maga $^{2}$ \\ ${ }^{1}$ Rostov State Transport University, Rostov-on-Don, Russia \\ ${ }^{2}$ Stamford International University, Bangkok, Thailand
}

\begin{abstract}
Twilight economic activity can be quite destructive for the state. If the obstruction of criminal economic activity is stopped, the state will begin to experience significant difficulties in ensuring the budget. After all, each, even small, committed illegal act carries even minor damage in a subjective sense, but if you analyze the statistical data of all such «small» crimes, the figures become quite impressive. The solution of such problems becomes the most relevant in modern conditions
\end{abstract}

\section{Introduction}

To date, corruption in the field of budget activity is the most misunderstood and very underestimated threat to the economic security of the state, since it has a fairly universal structure and nature. Corruption in the system of budgetary relations represents the subject in the role of the offender on the one hand, and on the other hand, the supervisory and controlling bodies of the executive power. Corruption in the budget system can be attributed rather to internal threats to economic security.

The sources of threats to economic security should be considered the contradictions of the economic interests of various actors, both inside and outside the socio-economic system.

Threats to economic security are complex in nature, since various external factors directly affect economic security in general. At the same time, it should be borne in mind that the combination of these factors is not only of an exclusive economic nature. The security of the economy is directly influenced by political, environmental, sociological, and other factors [1].

Russia's exposure to economic security risks is mainly reflected in the sources of proceeds of crime.

Organized crime is also defined as a threat in numerous government policies relevant to the definition of risk. Such formations are not considered as a separate category of predicate offenses, but rather as an organized way of committing another main type of criminal activity.

Based on the current situation, it is necessary to take into account the continuing risks of deterioration of the general economic situation, aggravation of geopolitical tensions and rather unfavorable events in the world financial markets, increased attention of the

*Corresponding author : ann-rgu@yandex.ru 
authorities should be paid to finding ways to increase the revenues of the regional budget system, including by reducing the level of shadow crime[2].

\section{Methods}

One of the main tools of counteraction in modern conditions is the formation of a system of personnel selection in relation to the personnel reserve of anti-corruption bodies. It operates on the basis of a methodological system for selecting the most suitable employees by passing the necessary test tasks, psychological contact dialogues, and conducting psychological stability experiments [3]. In addition to theoretical tests, future employees of anti-corruption agencies should be shown the necessary approved physiological results. First of all, attention is paid to the psychological stability, stress resistance and physical training of persons who have a desire to work in this area of public administration [4].

\section{Results}

On the basis of passing the described tests, a competition is held for those who wish to realize the desire for future employment. In addition, future employees undergo a largescale military medical examination, the results of which are an element of the basis for the suitability of applicants.

The rise of the shadow economy in Russia has a negative impact on all aspects of the life and activities of modern society. In addition, the growth of the twilight economy threatens the economic security of the state and, in turn, causes economic and social consequences [5].

Structural modernization and the creation of new specialized units to combat twilight economic processes will identify individual corrupt officials, but will not solve the problem in full, since the problem is more political and is associated with the lack of proper control over the executive authorities.

With regard to corruption, in order to organize counteraction to it, as a key element of the twilight economy on the part of anti-corruption bodies, in our opinion, there is a need to carry out measures in organizational, economic, legislative and service areas.

It is necessary to pay attention to an important factor, which is the need for highly qualified employees of anti-corruption bodies. Given this factor, it can be assumed that the work in these areas will reach a highly effective level. Within the framework of the study, as an action to counteract the twilight economy and corruption, in particular, it is proposed to organize a highly effective system of continuous training of employees of anti-corruption and corruption prevention bodies on the basis of creating a single, whole, generalized modern system of training employees throughout their working life.

In general, the process of continuous training of employees of anti-corruption bodies can be presented in the form of successive stages, the result of which will be directed to the transition to the format of their continuous training, which in turn will have a positive impact on the results of their activities.

The application of the proposed strategy will undoubtedly affect the process of forming a system of continuous training of employees of anti-corruption bodies.

An important success in the implementation of the system of continuous training can contribute to the comprehensive implementation of mentoring activities, supplemented by a system of training, both individual and group, which are aimed at forming the anticorruption stability of personnel, and, consequently, the overall anti-corruption protection.

Within the framework of the proposed innovation strategy, it seems appropriate to propose a program for testing the formation of anti-corruption stability of the personnel in 
the conditions of organizing the work of a mentor in the main areas of resistance to twilight economic topics.

In addition, it is proposed to introduce into the practice of management systems of individual approach (training), which will be aimed at the formation of anti-corruption stability, as an element of the twilight economy, of personnel.

The system of training for personnel can be represented from several directions (blocks), implemented in different time periods of official activity with different groups of employees:

- introductory training for first-time employees. During the training, it is necessary to explain the main duties, prohibitions, restrictions and requirements for official behavior that must be observed in order to counteract twilight economic activity, as well as to provide the person with a package of appropriate methodological materials. The scientific and methodological literature on countering the twilight economy sets as the optimal period for conducting this introductory training - 30 calendar days from the date of appointment of a person to an official position;

- regular training on countering the twilight economy, compliance with restrictions, prohibitions and requirements for official behavior for all employees. In the course of the training, special attention should be paid to the order of actions, according to which the current employees are obliged to comply with the norms of the provisions of the legislation, including the relevant administrative procedures established by the normative legal acts of the federal state body. It is also necessary to pay special attention to typical issues of conflicts of interest, which have the nature of arising in the implementation of anticorruption legislation, and necessarily indicate the process of their settlement. In the epilogue of the training, a detailed analysis of some of the most complex provisions of regulatory legal acts is required;

- coordination training of managers on knowledge of the Disciplinary Regulations of the internal affairs bodies in terms of prevention of corruption-dangerous behavior in the exercise of power and disciplinary rights.

The frequency of these events is at least once a year. In the course of training, there is a need to fill out a training instruction sheet, in which the employee personally certifies a reliable understanding of the information provided and the factor of its proper communication. The briefing sheets are stored in the supervisory file directly in the unit itself, which coordinates the fight against the twilight economy and anti-corruption protection

\section{Discussion}

It is currently impossible to accurately estimate the amount of proceeds from criminal activity. There is no general estimate of the value of the proceeds of crime. Based on this, the statistics are formed on the basis of an assessment of the damage and losses incurred as a result of all the criminal cases investigated. On average, from 2015 to 2019, the damage amounted to about 220 billion rubles.

The continuous stability of the tax system and the economic balance of the state are considered more relevant criteria for the stable financial and economic development of the country. However, the situation of the present fiscal system of Russia is quite difficult to call stable [6].

Based on the data of the Ministry of Finance of the Russian Federation, out of 85 subjects of the state, only 14 do not receive subsidies for the stabilization of economic viability. This suggests that regional entities are experiencing a significant lack of independent profit, which serves as a tool for implementing the obligations imposed on them by this legislation. 
The current situation of the economic situation is destructive due to the fact that the basic introductory figures, which are laid down in the basis of the federal budget for 2020, do not correspond to reality at the moment.

Thus, the average cost of Urals oil products for the first three months of 2020 was US \$ 29.17 per barrel, despite the fact that the budget of our state for 2020 was calculated based on the cost, which at that time was equal to US $\$ 58.45$ per barrel [7]. There is a need to take into account the fact that tax revenues to the state treasury from the oil refining segment systematically provide about one third of all possible total revenues of the budget system. Summing up the result, there is a critically significant discrepancy with the planned-actual result. As a result, there are significant threats to the Russian economy as a whole.

An objective example of twilight economic activity can be activities carried out in violation of labor legislation, including such factors as informal employment and activities without special permission. Thus, the twilight economy not only significantly underestimates the amount of tax revenues to the budget, but also actively contributes to the emergence of unforeseen expenditure obligations of the budget system [8].

The risks and threats to the state that arise in the implementation of twilight economic activities are quite multidirectional. As noted earlier, the main threat involves the shortfall of funds in the country's budget. It should be noted that through this circumstance, there is a factor of withdrawing money to the so-called «offshore».

In the event of tax losses in the budget (the amount of unpaid taxes), the state cannot finance its obligations to the required extent. Thus, the components of legal economic activity are subject to additional taxation. There is a tightening of the tax burden. The increase in the tax burden leads to further growth of the twilight economy. In addition, this factor also leads to a tightening of budget constraints in the public sector.

The leading position in the share of the informal sector is occupied by the sphere of real estate transactions, $6.3 \%$ of GDP. This is equal to about half of the entire gray economy of the state. At the same time, the factor of most twilight operations belongs to the informal economy $-70.6 \%$ [9].

In public administration and military security, as well as including the water supply and waste disposal sector, there is almost no informal activity.

According to the Central Bank, the service sector (with the exception of logistics), the construction sector and wholesale and retail trade are the sectors that generate the most demand for shadow financial services in Russia. According to the regulator, in 2018, the country illegally left the amount of 73 billion rubles. The Central Bank estimated the cash withdrawal market at 176 billion rubles [10].

The activities of structural divisions for the protection of budget funds are aimed at a special category of crimes in the economic sphere. The main range of economic crimes includes such criminal offenses as:

- fraud;

- embezzlement or embezzlement;

- illegal banking activities;

- evasion of taxes, fees payable by the organization, and (or) insurance premiums payable by the organization-payer of insurance premiums.

As noted by the information and statistical portal RBC, as of August 20, 2020, the number of cases of fraud with electronic payments increased eight times compared to the same period in 2019. The first half of 2020 included 6,613 registered cases of fraud, through the use of electronic means of payment [11].

Assessing the dynamics of the commission of criminal offenses under the article «fraud», it should be noted that in the first half of 2019, employees of the state executive power registered 100,271 crimes. By comparison, in the first half of 2020, 157,297 criminal 
cases were under production. Among this indicator, the number of registered crimes amounted to 105,681 , and compared to the previous year - increased by $5.4 \%$.

Also, considering the period of the first half of 2020, it is impossible not to pay attention to a significant increase in crimes that were registered under the article «fraud in receiving payments». The number of registered cases under this article amounted to 4,441 criminal offenses, which in turn is $27.6 \%$ more than in 2019.

Analyzing this statistical period, we should note a slight increase in the number of crimes by the first half of 2020 in relation to 2019 in the field of economic activity, as well as crimes of «Fraud». This trend is due to the overall macroeconomic situation in the Russian Federation.

\section{Conclusions}

The study of the causes and factors of the twilight activity of the state showed that the areas that are most exposed to the twilight economy in Russia are: the industry, the fuel and energy complex; the sphere of financing targeted programs and national projects; the banking sector; organized crime, in particular drug trafficking; the informal economy sector; the sphere of criminal activity aimed at consumer markets and agro-industrial complexes.

It seems that these areas should remain the objects of primary increased attention in the implementation of systemic measures to combat the twilight economy. Special attention should be paid to the analysis of the causes and factors that led to the commission of a particular offense.

\section{References}

1. Tadtaev, D.M. Twilight economy as a system threat to the economic security of the region. Rossiyskoe predprinimatelstvo, 14(6), 138-142. (2013)

2. Ukhanov, V.V. Approaches to the definition of the concept and nature of shadow economy and analysis of its magnitude. Rossiyskoe predprinimatelstvo, 18(22), 34053418. (2017)

3. Sysoeva E. V. Methodological foundations of countering the shadow economy as a threat to Russia's economic security, Economic Science today: theory and practice: proceedings of the VI International Scientific and Practical Conference (Cheboksary, 24 March 2017), Editorial board: B. K. Meymanov [et al.], Cheboksary: CNS "Interactive Plus", pp. 21-37. (2017).

4. Zhigunova A.V., Bek-Murza R. A. Shadow economy as a threat to the economic security of subjects of various levels, Science and education: economy and economy; entrepreneurship; law and management, No. 2 (117). pp. 7-10. (2020)

5. Burov V. Yu. Shadow economic activity of business entities as a factor in the development of economic crime, The shadow economy. - Volume 3. - No. 2. - pp. 8796. (2019).

6. Udovin V. S., Bakun M. V., Borkova E. A. Expert assessment of threats to the economic security of the region (on the example of St. Petersburg), Volume 9, No. 3, p. 1827-1838. (2019)

7. Shadow business in numbers [Electronic resource] // http://www.forbes.ru -Official financial and economic magazine «Forbs»-URL: http://www.forbes.ru/ekonomikacolumn/vlast/65945-tenevoi-biznes-v-tsifrah 
8. Zhigunova A.V., Bulgakov A.D. Shadow economy as a factor of violation of economic security, Science and education: economy and economy; entrepreneurship; law and management. No. 3 (118). pp. 7-10. (2020)

9. Akopyan E. A. Experience of fighting the shadow economy in european countries. Bulletin of the University.(1):96-101. (2018)

10. Maga A. A., Nicolau P. E. Analysis of the scale of the shadow economy in the Republic of Uzbekistan, The shadow economy, Volume 3, No. 2, pp. 115-126. (2019).

11. Shumskik A. A. Foreign experience of countering the shadow economy, Actual issues of national economy development, PP. 519-527 (2017). 